\section{Democratic Deficits in Indian Political System}

Dr Jitendralal Borkakoti ${ }^{\dagger}$

On Monday 10 August 2015, Rajya Sabha Chairman Hamid Ansari, welcomed and introduced a Parliamentary Delegation from Bhutan to the Rajya Sabha, and said "We hope that during their stay here they would be able to see and learn more about our political system". And at that point, there was a ripple of laughter from the members who saw the irony of the word "learn", as they already seemed to know about the impending disruptions to the session. The Chairman began the session by saying "Question 211", and immediately, the Opposition members started shouting slogans like football hooligans. And the session was adjourned for 2 hours. On 11 August 2015, the Lok Sabha was interrupted by the opposition members by occupying the Well of the House, and Speaker Sumitra Mahajan said "40 MPs want to snatch the rights of 440 MPs who want to participate in business" (noting that the Congress has only 44 members). The area around the desk of the Secretary-General that was in front of the Speaker's Chair has been fenced to keep the unruly members from crowding the area after this protest. It ill behoves the MPs to behave in such a shameful manner in a hallowed institution of democracy, where thuggery now seems to replace reasoned debates and arguments. These are fundamental symptoms of democratic deficits.

India's Parliamentary democracy is still evolving, arguably still at a nascent stage, and immature behaviour of MPs is not surprising. Nevertheless, it is thousand times better to have a democratic system than an authoritarian dictatorship. It also should not be surprising that Indian democracy suffers from democratic

\footnotetext{
${ }^{\dagger}$ Former Faculty member of Middlesex University Business School, London and currently, President of Assam Forum of Great Britain. Email: j_borkakoti@hotmail.com
}

(C)2016 Borkakoti. This is an Open Access article distributed under the terms of the Creative Commons Attribution License (http://creativecommons.org/licenses/by/2.0), which permits unrestricted use, distribution, and reproduction in any medium, provided the original work is properly cited. deficits. The concept of democratic deficit has been defined in various ways. One broad way is to consider citizens' aspiration for democratic performance in delivering national services and their perception of satisfaction. In a democratic society there should be a balanced equilibrium between democratic performance and citizens' satisfaction. If satisfaction is less than aspiration, then there is a democratic deficit, because then the country can move to an alternative political system (as for example, an authoritarian system). This concept is very broad, but it still has some relevance. The notion of democratic deficit was first mooted in the context of the European Union where the European Commission - an unelected body has considerable powers without democratic accountability and transparency as opposed to the European nation states. This concept evidently is not applicable to Indian democracy.

Democracy in India is unique not only because it is a country with a large population but also, and in fact more so, because of a high degree of diversity in language, culture (including music, dance and literature), religion, tribes, caste, personal economic status and regional economic status. One historical contribution of the British Raj was the introduction of the rudimentary elements of Parliamentary democracy in terms of the elections to establish Home Rule. However, the foundation of democracy in terms of people's patriotic concern about the country was set by the freedom movement. Proper, legitimate and efficient functioning of a democratic system requires rules and regulations; and India is blessed with a much admired Constitution. Proper functioning of a democratic system also requires political organizations from the grass root levels; democracy cannot be a top-down system.

Democratic deficits in India may emanate from many sources: (1) iniquitous and inefficient representation in democratic institutions, (2) 
ineffective media, (3) poor governance and corruption, (4) top-down governance of the political parties, (5) lack of public participation, and unfortunately (6) lack of strong leadership and moral backbone of most politicians. Although it is not an exhaustive list, it does provide us with a framework to discuss the reasons for democratic deficits in India.

In a diverse country like India, it is quite difficult to achieve an optimal representation in terms of seats in the Parliament, or for that matter, in the State Assemblies. Historically, all over the democratic world, politics has been dominated by the elite class consisting of people who are intellectually, economically, and socially powerful. This perhaps is the nature of the beast. But in India, it specifically becomes a problem because of the sheer diversity of the society. An MP or an MLA is expected to represent all the constituents of his/her constituency irrespective of caste, creed, ethnicity, economic status, language etc. But in practice, do the downtrodden get the same access to the member as somebody from the educated elite group? If a constituency is dominated by, say, the upper caste, will the problems and aspirations of, say, the Dalits, get a voice? If not, as often is the case, there is a democratic deficiency in terms of democratic representation.

The role of an independent and strong media is vital not only to disseminate political, social and economic debates but also to keep a critical eye on what the politicians are up to. Ideally a voter is expected to decide, which candidate or political party he/she will vote for, on the basis of a reasonable analysis of what is promised by the politicians and other information as disseminated by the media. More fundamentally, media's role is to expose corruption, poor governance, unreasonable and illegal acts committed by the government at any level or by the MPs or MLAs or by any unscrupulous citizen. A free and independent Press is the bulldog that keeps kleptocracy at bay. But, it is alleged that journalists, who act to find more about any alleged corruption or crime committed by a politician or a bureaucrat, are often threatened to be silent or even allegedly murdered, or in certain cases, bribes are offered. Even, it is alleged that Newspapers are bribed by politicians or Political Parties to publish reports which are relatively favourable to the briber and nasty to the opponents. Many regional TV channels are owned by political leaders, and this prevents objective reportage and investigative journalism. This is a truly serious democratic deficit, and a dangerous one, as the history of the past Communist countries reveals.

Poor governance and rampant corruption often characterise dysfunctional democratic systems. The blatant corruption that uses the modus operandi of false LOC (Letter of Credit) is nothing but day light robbery from the national coffers. These immoral and shameless perpetrators get the money for doing fictitious work, as for example, they claim for some construction work or for some supply to the government which never took place in reality. The citizens are deprived of the benefits that could have accrued to them from the stolen money. Also, in this context, poor governance creates similar loss to the citizens. For example, if the State government cannot use the funds allocated by the Central Government, and funds are returned to the Centre, the citizens of that State have missed out on the benefits that could have accrued to the State. These characteristics are symptoms of a dysfunctional democratic system, and the degree of dysfunctionality represents the extent of democratic deficits. Specifically, such deficits become self-sustaining, if the same Party and the same MLAs or MPs keep getting elected, and if the perpetrators of corruption succeed in manipulating the judicial system to keep out of jail.

There is a basic democracy deficit in the way Indian political parties conduct their administration. This may be called top-down politics. There is a lack of internal democracy in most major political parties in India. All parties are led by charismatic leaders, and the second rung of leadership is thwarted. If Sonia Gandhi is allowed to decide who the President of the 
All Assam Congress Party should be, it certainly is not a democratically run Party. Internal democracy in the Party should allow the members of the Assam Congress Party to elect their own President. In the United Kingdom, the Constituency Party is vibrantly democratic. The Chairman of the Constituency Party is powerful; candidates are elected by democratic votes after each candidate makes a speech. In India, candidates are selected at the Central Office of the Parties, and there is a lot of horse trading in this process. Sanjay Singh from UP was imposed on Assam as a candidate for Rajya Sabha, and the Chief Minister made valiant efforts to make sure that Sanjay Singh got elected to Rajya Sabha. The constitutionally endowed rights of the MLAs were swept aside, and, as 'ordered' by the High Command, they voted for Sanjay Singh who knows very little about Assam or the Assamese people and culture. This is not democracy, this is oligarchy. Democracy must be built up from grass root and we should have a bottom-up system.

Public participation in political decision making process is very important; just because you go to vote once in 5 years, it does not make democracy an optimal and efficient political system to deliver good governance and economic welfare. There are three factors we need to discuss here. First, the public must think and study the social, political and economic problems; it is a necessary condition in democracy that those who vote must know the burning issues of the country and have a good grasp of the solutions offered by the Political Parties. The citizens must be able to analyse whether the policies offered are feasible and realistic. It therefore seems that democracy works more efficiently in a country populated by well-educated citizens, and to that extent, democratic deficits are reduced. However, Party manifestos and political agendas are not that important in Indian elections, as the political parties try to woo the electorate over caste alliances; or the incumbent governments may announce populist measures to gain favour with electorate. Second, the majority of the population in India live in rural areas and they are too busy in eking out a living with little time to spare to ponder the great social and economic issues. But, as often is the case, they have shown their awareness of the issues and have voted in a wise manner in the recent election in Bihar, a relatively poor State, and brought back JDU because of their competence and good performance. However, the relatively less-educated rural folks are often socially compromised to vote according to religion, caste or language lines, and thus, democratic deficits are almost built into the system in India. This also applies, perhaps to a lesser extent, to the educated middleclass people in urban areas as well. People vote along those lines because India primarily has developed a patronage democracy where identity based on caste, religion or language determines access to resources. This also negatively affects the optimality of both selection and election process of candidates to Parliament or Legislative Assemblies. Third, there is political thuggery in selecting candidates by political parties; and the election process is often compromised in terms of the electorate being either bribed or threatened or simply physically barred from voting. This adds substantial democratic deficits. More importantly, many elected MPs and MLAs, who are law makers, are themselves convicted criminals or are citizens with criminal cases pending against them in Courts of Law. The rule "innocent until proven guilty" provides a fig leaf for the elected MPs or MLAs who have been charged with crimes to continue as if nothing has happened. Also, a potentially criminal MP likes the way the justice system work in India - it takes a long time. It is a sad reflection of Indian democracy that $186 \mathrm{MPs}$ (about 34\%) in the 2014 Lok Sabha have criminal cases pending against them (and the figure was 158 about 30\% in the 2009 Lok Sabha, indicating an accelerating trend). This is a serious democratic deficit, and the rules of the electoral process must be changed in India. This is also a catch-22 situation, because the criminal or crimeaccused MPs have been deliberately delaying successful legislation of laws that will keep them out of the Parliament. In the United 
Kingdom, the mother of democracy, MPs accused of any serious crime immediately resign; and that is how democracy should function. Such good political behaviour emanates not only from society's expectations but also from a sense of self-respect of the MPs. Why does the Indian society allow a politician convicted of serious crimes to be an MP? A politician in Bihar was sent to jail, and his wife was managing his "political empire". When people become shameless and corruption becomes institutionalised in a country, it will take many years to reform the democratic processes.

Lastly, an efficient democracy requires strong leadership with a vision for the country. India needs a visionary leader who is wise, strong and determined, and who can survive the dirty politics in terms of mud thrown at him/her.
Despite having much democratic deficits, as discussed above, Indian democracy has a fundamental vibrancy in the sense that the electorate has thrown out governments because of incompetence, corruption and so on. Indira Gandhi's attempt to hold onto power by declaring emergency backfired, and the Congress Party paid a heavy price for it and lost the 1977 General Election. It is, in fact, a great achievement of India that the democratic process, despite peoples' aspirations not being fulfilled, is slowly but steadily strengthening, notwithstanding her immense diversities. Democratic deepening is gathering strength also as democratic institutions like Panchayats are taking roots at local levels, and as citizens from the downtrodden communities are becoming assertive. There is no doubt that there is light at the end of the tunnel. 